\title{
Anosmia as a presenting symptom of SARS-CoV-2 infection in healthcare workers - a systematic review of the literature, case series, and recommendations for clinical
} assessment and management *

\author{
Matt Lechner, 1 , ,\#, Deepak Chandrasekharan 1, , Kiran Jumani', Jacklyn Liu², \\ Simon Gane ${ }^{3}$, Valerie J. Lund ${ }^{3}$, Carl Philpott ${ }^{4,5}$, Samuel Jayaraj' \\ ' Whipps Cross University Hospital, Barts Health NHS Trust, UK \\ ${ }^{2}$ UCL Cancer Institute, University College London, London, UK \\ ${ }^{3}$ Royal National Throat, Nose and Ear Hospital, UCLH Foundation Trust, London, UK \\ ${ }^{4}$ The Norfolk Smell \& Taste Clinic, Norfolk \& Waveney ENT Service, UK \\ ${ }^{5}$ Norwich Medical School, University of East Anglia, Norwich, UK
}

Rhinology 58: 4, 394 - 399, 2020 https://doi.org/10.4193/Rhin20.189

*Received for publication:

April 24, 2020

Accepted: May 3, 2020

contributed equally

\begin{abstract}
Background: Healthcare workers are at the forefront of the ongoing COVID-19 pandemic and are at high risk for both the contraction and subsequent spread of virus. Understanding the role of anosmia as an early symptom of infection may improve monitoring and management of SARS-CoV2 infection.
\end{abstract}

Methodology: We conducted a systematic review of the literature of SARS-CoV2 infection/COVID-19 and anosmia to help inform management of anosmia in healthcare works. We report a case series of healthcare workers, who presented with a loss of sense of smell secondary to COVID-19 infection to demonstrate management principles. RT-PCR was used to confirm COVID-19 positivity and psychophysical testing of olfaction was performed using the British version of the University of Pennsylvania Smell Identification Test, UPSIT.

Results: The systematic literature search returned 31 articles eligible for inclusion in the study and informed our recommendations for clinical assessment and management. All three healthcare professionals who presented with loss of sense of smell subsequently tested positive for SARS-CoV-2. Psychophysical testing of olfaction using the UPSIT confirmed mild and moderate microsmia in two, respectively, and normosmia at day 17 in one.

Conclusions: Olfactory ( \pm gustatory) dysfunction is indicative of COVID-19 infection and thus has important implications in the context of healthcare workers, or key workers in general, who work in close contact with others if not recognised as suffering from COVID. This leads to a potentially higher likelihood of spreading the virus. In conjunction with our literature review these findings have helped with creating recommendations on the assessment and management of olfactory dysfunction during the ongoing COVID-19 pandemic, both for healthcare workers and patients.

Key words: coronavirus, SARS-CoV-2, COVID-19, olfaction disorders, anosmia, pandemic, coronavirus infection

\section{Introduction}

Post Viral Olfactory Loss (PVOL) represents approximately $11 \%$ of cases of olfactory dysfunction in the community ${ }^{(1)}$ but typically accounts for $20-25 \%$ of cases presenting to specialist clinics(2,3). Coronaviruses have previously been demonstrated to be among the respiratory viruses that can cause $\mathrm{PVOL}^{(4)}$. Increasing number of reports of COVID-19 positive patients describing a loss of smell and taste have been seen internationally since initial reports from China ${ }^{(5)}$, Korea ${ }^{(6)}$, Italy ${ }^{(7)}$ and $\operatorname{Iran}^{(8)}$. These may be the only symptoms, early presenting symptoms, or be part of mild 
flu-like symptoms $s^{(9,10)}$. This topic has also received significant press coverage, especially with regard to potential public health implications. The World Health Organisation has recently added anosmia to its list of official symptoms and as such, patients experiencing these symptoms need to follow self-isolation guidance. Importantly, individual healthcare institutions may or may not be following these guidelines and awareness of this update may be limited. It is known that the viral load is comparable between symptomatic and minimally symptomatic/ asymptomatic individuals thus if people with anosmia were to have COVID-19, transmission is possible ${ }^{(11)}$.

The debate is ongoing as to what extent loss of smell and taste in SARS-CoV-2 infection is caused by localised olfactory cleft oedema, architectural deformity of the olfactory neuroepithelium or direct neuroinvasion of the olfactory nerve pathways. In typical viral mediated olfactory loss, the pathophysiology involves loss of cilia of the olfactory sensory neurons ${ }^{(12)}$. Furthermore, the loss of taste more likely reflects loss of flavour perception due to loss of retronasal olfaction rather than the loss of the sense of taste per se.

There have been reports of increase in anosmia symptoms and a recent case report of anosmia in a healthcare worker in Madrid who was subsequently diagnosed with SARS-CoV-2. This raises questions regarding the significance of anosmia in COVID-19 - both generally in terms of anosmia management, but also of particular concern to healthcare workers, how to advise healthcare workers who present with such a symptom from a public health aspect in terms of isolation and testing.

Here we present the results of a systematic review of the currently available literature on anosmia in COVID-19 and provide a summary table of the relevant findings. Secondly, we present three representative cases of healthcare workers presenting to our clinics with anosmia as their primary symptom of COVID-19. Finally, combining the findings from the review and the case series together, we provide recommendations on how to adapt existing anosmia management protocols in the context of $\mathrm{CO}$ VID-19, particularly focussing on healthcare workers.

\section{Systematic review of the literature}

A systematic literature search was performed on PubMed on 27 April 2020 using the following search terms: ((()((SARS-CoV-2) OR 2019-ncov) OR coronavirus) OR corona virus) OR COVID-19) OR COVID)) AND (((((anosmia) OR hyposmia) OR loss of smell) OR smell) OR olfact*) OR cacosmia) OR dysosmia). We also screened BioRxiv and MedRxiv on for preprints related to anosmia in SARS-CoV-2. Inclusion criteria were papers describing reports of anosmia in patients in the context of COVID-19, regardless of patient demographics, number of cases, and method of

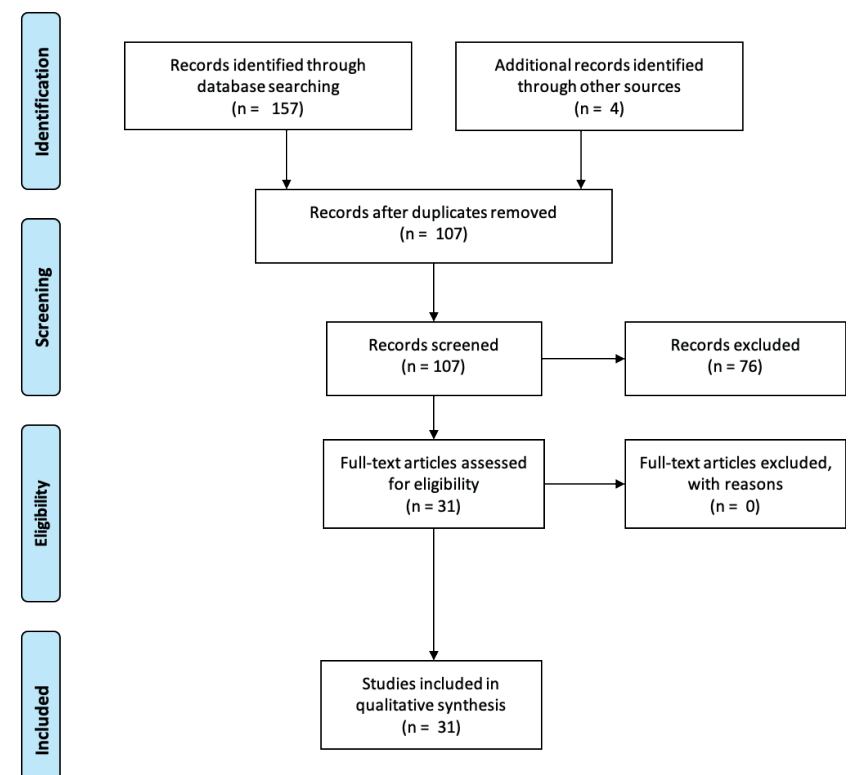

Figure 1. PRISMA flow diagram of literature search and screening for relevant studies.

anosmia assessment. Date criteria were from 31/12/2019 to 27/04/2020. We hand searched citing literature and references of included studies. Papers that did not provide patient level data were not included for data extraction. We did not search for or include articles in the lay press or online forums. We also did not screen studies reporting general clinical features of anosmia as a recent review from The Centre for Evidence Based Medicine has assessed these studies already and found the evidence base was inconclusive ${ }^{(13)}$. The authors did recommend incorporation of olfactory history and assessment in further studies. This conclusion was also reached by Lovato and colleagues who provide an overiew of upper respiratory tract symptoms in COVID-19(14). Finally, any identified reviews were used to identify studies but were not themselves included in the data extraction. Data extraction included: number of patients, study method, onset of anosmia relative to COVID-19 symptoms, COVID-19 positivity and method of testing, time for recovery from anosmia, and summary findings. Formal evaluation and assessment of risk of bias of included papers was not performed.

We found 107 unique papers of which 31 were eligible for inclusion in the study (Figure 1). Summary findings of the included studies are in Supplemental Table 1 for reference. The 31 papers included work from multiple continents. The majority were cross sectional studies, case series or case reports. Diagnosis of smell dysfunction was variable and used a variety of published and custom designed self-reported surveys of anosmia/COVID-19 symptoms either in person, online, or via apps. Formal psychophysical testing of olfaction used the Nez-du-Vin, country specific UPSIT or the Sniffin' Sticks. 
Table 1. Summary of case series.

\begin{tabular}{|c|c|c|c|c|c|c|}
\hline Case \# & $\begin{array}{l}\text { Agel } \\
\text { Sex }\end{array}$ & Patient History & Other Symptoms & $\begin{array}{l}\text { UPSIT } \\
\text { Score }\end{array}$ & $\begin{array}{l}\text { COV- } \\
\text { ID-19 } \\
\text { RT-PCR }\end{array}$ & Other Medical History \\
\hline 1 & $43 / \mathrm{M}$ & $\begin{array}{l}\text { Presented with loss of smell, } \\
\text { initial onset one week prior to } \\
\text { presentation }\end{array}$ & $\begin{array}{l}\text { Feeling hot and cold, runny nose, } \\
\text { mild bilateral nasal obstruction, } \\
\text { no cough, persistent olfactory } \\
\text { dysfunction }\end{array}$ & 25 & Positive & $\begin{array}{l}\text { Gastric sleeve operation, hernia } \\
\text { repair, smoker ( } 5 / \text { day) }\end{array}$ \\
\hline 2 & $37 / M$ & $\begin{array}{l}\text { Presented with loss of smell five } \\
\text { days prior to presentation, subse- } \\
\text { quent metallic smell and taste }\end{array}$ & $\begin{array}{l}\text { Recurrent temperature, myalgia, } \\
\text { fatigue, dry cough, runny nose } \\
\text { and sneezing }\end{array}$ & 28 & Positive & $\begin{array}{l}\text { Septoplasty, thoracotomy and } \\
\text { pleurectomy of right lung fol- } \\
\text { lowing spontaneous pneumotho- } \\
\text { rax, toxoplasmosis of right eye }\end{array}$ \\
\hline 3 & $53 / \mathrm{M}$ & $\begin{array}{l}\text { Presented with loss of smell, } \\
\text { initial onset } 2 \text { days after flu-like } \\
\text { symptoms }\end{array}$ & $\begin{array}{l}\text { Mild flu-like symptoms, resi- } \\
\text { dual tiredness after } 14 \text { days } \\
\text { self-isolation, early loss of smell } \\
\text { (recovered) }\end{array}$ & 34 & Positive & \\
\hline
\end{tabular}

Anosmia is presenting as the primary symptom or as an early symptom in patients who have tested COVID+. In a European study, $11.8 \%$ of patients reported anosmia onset before other otorhinolaryngological symptoms ${ }^{(15)}$. In the American Academy survey, $26.6 \%$ reported it as an isolated initial symptom ${ }^{(16)}$ and the Centre for Disease Control and Prevention has just added this to the symptoms related to COVID-19, but individual institutions may or may not be testing based on this symptom. Other surveys did not have a sufficient tested population. Thus, identifying olfactory dysfunction could potentially have a role in the diagnosis of COVID-19. One study formally assessed smell and taste loss in a stepwise regression model and found them to be strongly associated with COVID-19. In fact it was the strongest predictor from a list of other symptoms and had a positive predictive value of $67 \%$ (17); the caveat of this study was that only $0.1 \%$ of all participants had been tested for COVID-19. Anosmia may also have potential to discriminate COVID-19 from other viral respiratory illnesses ${ }^{(18,19)}$.

Where anosmia is reported in the context of COVID-19, due to the short time that has elapsed since the pandemic started, data on the recovery of olfactory function is not always available. In the studies that have reported it in COVID-19 tested patients, albeit from surveys, complete resolution was seen in 13\% and partial resolution in $14 \%$, with a mean time to improvement of 7.2 days $^{(16)}$. This is lower than the recovery rates reported by Lechien and colleagues ${ }^{(15)}$ who suggest a short term recovery rate of $44 \%$ in 59 patients who had clinically recovered from COVID-19, and also lower than the $73 \%$ that reported by Levinson and colleagues ${ }^{(20)}$, although only 15 patients make up this cohort. Recovery seems to take place within a few weeks but this may be due to short follow up and recovery may happen in others over a longer timeframe. The coming months will begin to reveal whether COVID-19 will leave a larger burden of persistent PVOL patients in the community.
Correlations suggested between disease mild severity disease and anosmia are necessarily preliminary. Whilst some suggestions are made that anosmia is associated with milder disease ${ }^{(21,22)}$, this could be confounded by the inability to assess/self-report anosmia in those patients with severe disease in intensive care settings. However, a higher viral load, potentially indicative of more severe disease, does seem to be associated with a shorter duration of anosmia ${ }^{(23)}$.

Whether the underlying cause of anosmia is conductive or sensorineural was attempted to be addressed by two studies that assessed imaging of the olfactory system ${ }^{(24,25)}$. Anosmia was found to be obstructive in nature rather than neural with a normal olfactory bulb. However, the presence of nasal obstructive symptoms (albeit subjectively reported) in patients with anosmia varied widely in the included studies. The reports of ACE2 receptor expression in non-neuronal cells and supporting olfactory sustentacular cells may support this finding (26-29). Alternatively, the virus could migrate from these cells if it were neurotropic ${ }^{(30,31)}$.

Healthcare workers suffering from anosmia were reported in multiple studies and in the American Academy data, approximately a third of patients were healthcare workers(16). Whilst this could be due to selection bias as only healthcare workers could enter data into the reporting tool, it suggests that both anosmia and COVID-19 in healthcare workers is an issue that is important to consider. Below, we present three illustrative cases to highlight issues to consider in the assessment and management of healthcare workers with anosmia.

\section{Case series}

Three healthcare professionals, a 43-year-old male nurse, a 37-year-old male Specialty Registrar in Rheumatology and a 53-year-old male Consultant Anaesthetist, presented to our ENT 
clinics with loss of their sense of smell and a history of other mild flu-like symptoms (Details in Table 1) in the last 3 weeks. In view of the emerging literature, we performed a COVID-19 real-time reverse transcription polymerase chain reaction (RT-PCR) swab test and confirmed COVID-19 infection. Formal assessment of their olfactory function was performed using the British version of University of Pennsylvania Smell Identification Test (UPSIT), a validated psychophysical test in line with the guidelines in the Position paper on olfactory dysfunction ${ }^{(32)}$. This confirmed moderate microsmia (UPSIT score of 25/40) in patient 1, mild microsmia (UPSIT score of 28/40) in patient 2 and the third patient told us that he felt that his sense of smell had already almost recovered at the time he was seen and he scored $34 / 40$ on day 17 . All three individuals were advised to contact occupational health for further advice, were given safety advice regarding his olfactory dysfunction, and referred to a website with validated patient information on their condition and guidance on olfactory training (www.fifthsense.org.uk).

\section{Discussion and recommendations}

The presence of anosmia in the context of COVID-19 raises three main questions. Firstly, if a person develops isolated anosmia, what is the likelihood they already have, or will go on to develop, COVID-19? Secondly, what is the best strategy for treatment for anosmia in the context of COVID-19 and what is the prognosis for recovery of olfactory function? Finally, what is the underlying mechanism and pathophysiology of the anosmia?

At present the answers to the above questions are limited until high-level robust evidence available. A global survey of COVID-19 related chemosensory impairment is currently underway: https://gcchemosensr.org.

The mechanism at present is also debated with some suggesting the SARS-CoV-2 virus is neurotropic but others arguing the expression of target receptors in non-neuronal olfactory/ nasal region cells suggests a possible inflammation with an obstructive cause of anosmia. There is also the possibility that acquired mutations of SARS-CoV-2 have enabled the virus to alter its pathogenicity and which may play a role in altering disease presentation ${ }^{(33)}$. Nevertheless, the work presented here does highlight that anosmia in healthcare workers may be indicative of COVID-19. When combined with the preliminary evidence that anosmia is a strong diagnostic symptom, this has potentially important implications when anosmia is considered in the context of healthcare workers, or key workers in general. The ongoing potential contact with other people due to the nature of such professions means someone with COVID-19 is potentially at higher likelihood both of contracting the virus and of spreading the virus if they were to catch it - anosmia may be an early symptom of this. There are limitations in the evidence presently available. The majority of studies are cross sectional or retrospective with limited prospective follow up. Many cases rely on self-reporting and COVID-19 laboratory confirmed numbers are small. Where testing is performed, it relies on the RT-PCR test which the Centre for Evidence-Based Medicine reported to have as high as a $30 \%$ false-negative rate ${ }^{(34)}$. Finally, formal assessment of anosmia varied with multiple survey types used and assessment modalities hence comparability and evidence synthesis are limited to comparable studies.

Whilst the recent work by Hunter and colleagues ${ }^{(35)}$ suggests that there is a comparable rate of COVID-19 positivity in frontline clinical staff compared with non-clinical staff in hospitals, the authors suggest this shows isolation and PPE measures are adequate at present to prevent nosocomial infections and the transmission may reflect that from the community. This is supported by a reduction coinciding with the UK wide lockdown timing. However, the authors only tested staff with new continuous cough and fever as per current PHE recommendations rather than staff screening for those with wider symptoms or if asymptomatic. Therefore, the work presented here is of relevance as it shows that testing may potentially need to be extended to a wider spectrum of symptoms, particularly if community transmission seems to be the prime vector. The other caveat is that a comparison with other institutions and control groups of non-hospital key-workers would also be helpful.

Our recommendations for the management of patients, particularly healthcare workers, with symptoms of hyposmia/anosmia during the COVID-19 crisis are guided by the Position Paper on Olfactory Dysfunction ${ }^{(3)}$ and include:

- Discussion regarding isolation and testing for COVID-19 with institutional occupational health service.

- Full remote history asking about onset, duration, other COVID-19 symptoms, exposure risks, past otorhinolaryngological history, and general medical history.

- If no other red flag symptoms (such as facial pain, serosanguinous discharge, visual changes) and acute onset particularly in relation to flu-like symptoms during the COVID-19 pandemic, imaging (CT/MRI) is not indicated.

- Ideally psychophysical testing ${ }^{(30,32)}$ but this may be limited by resource and default to self-reporting, although individuals can be asked to self-test at home against common food cupboard items. Psychophysical testing, which can be done remotely (e.g. country specific UPSIT) ${ }^{(36)}$ will avoid direct contact with patients.

- Provide advice regarding safety precautions including need for gas alarm, smoke alarm, and care with use by dates for food. Patients can be directed to relevant online resources such as the Fifth Sense website.

- Current guidance is to avoid oral steroids due to the poten- 
tial risk of worsening COVID-19, as evidence from previous SARS in 2004 where systematic corticosteroids led to an increase in viral shedding ${ }^{(37)}$. However, current trials, such as the RECOVERY trial for COVID-19 include systemic steroids in a treatment arm, so this advice may alter if these trials show evidence of benefit or at least no precipitation of deterioration in recipients. Intranasal steroids are unlikely to be harmful in patients already taking them but a fear of promoting viral shedding in new patients means advice currently is to avoid them.

- Provide advice regarding olfactory training (e.g. from organisations such as Abscent/Fifth Sense).

- Rhinology follow-up after crisis. Only consider an MRI olfactory protocol if there are any other concerning symptoms, but if there is a clear temporal history relating to the viral infection, especially where COVID+ve status is confirmed, an MRI scan is not indicated.

National organisations in the UK and USA have recommended the addition of anosmia as a diagnostic symptom in the WHO criteria and potentially isolating if new onset anosmia is experienced as a symptom. Future work regarding the diagnostic utility and prognosis in large all-comer cohort studies with sufficient laboratory-based testing will hopefully provide stronger evidence for ongoing diagnosis and care of these patients. Until this time, we hope the evidence summary and recommendati- ons in this work will be of use to care providers, researchers and public health organisations in their work.

\section{Conclusion}

Loss of sense of smell and taste appears to be indicative of COVID-19 infection and has important implications in the context of healthcare workers, or key workers in general, who are in ongoing close contact with others due to their work. This leads to a potentially higher likelihood of contracting and spreading the virus. This literature review has helped to underline the clear link of loss of the senses of smell and taste during the ongoing COVID-19 pandemic, both for healthcare workers and patients. We hope our illustrative case series and recommendations can thus be applied to help manage these presentations of anosmia in the current climate until further evidence is available.

\section{Authorship contribution}

$M L$ has led on the concept and written the initial draft with the help of DC, who conducted the systematic review. KJ, JL, SG, $\mathrm{VJL}, \mathrm{CP}$, and $\mathrm{SJ}$ helped writing the manuscript, reviewed final draft and advised on the clinical guidelines for the management of patients with symptoms of hyposmia/anosmia during the COVID-19 crisis.

\section{Conflict of interest}

The authors declare no conflicts of interest relevant to this work.

\section{References}

1. Damm M, Temmel A, Welge-Lussen A, Eckel, HE, Kreft M-P, Klussman JP, et al. [Olfactory dysfunctions. Epidemiology and therapy in Germany, Austria and Switzerland]. HNO 2004; 52: 112-120.

2. Philpott CM. Smell and Taste Disorders in the UK: First experiences with a specialised smell and taste outpatient clinic. Bulletin of the Royal College of Surgeons of England 2014; 96: 156-159.

3. Fokkens W.J., Lund V.J., Hopkins C., Hellings P.W., Kern R., Reitsma S., et al. European Position Paper on Rhino-sinusitis and Nasal Polyps 2020 Rhinology. 2020 Suppl. 29: $1-464$.

4. Suzuki M, Saito K, Min WP, Vladau C, Toida $\mathrm{K}$, Itoh $\mathrm{H}$, Murakami S. Identification of Viruses in Patients with Postviral Olfactory Dysfunction. Laryngoscope 2007; 117: 272277.

5. Mao L, Jin H, Wang M, Hu, Y, Chen $\mathrm{S}$, He Q et al. Neurologic manifestations of hospitalized patients with coronavirus disease 2019 in Wuhan, China. JAMA Neurology 2020.

6. h t t ps://news.joins.com/ article/23738003?cloc=joongang-mhomegroup6

7. Giacomelli A, Pezzati L, Conti F, Bernacchia $D$, Siano $M$, Oreni $L$, et al. Self-reported olfactory and taste disorders in SARS-CoV-2 patients: a cross-sectional study. Clin Infect Dis. 2020 Mar 26. pii: ciaa330. doi: 10.1093/ cid/ciaa330. [Epub ahead of print].

8. https://en.radiofarda.com/a/loss-of-senseof-smell-among-iranians-coinciding-withcoronavirus-epidemic/30478044.html

9. Gane SB, Kelly C, Hopkins C. Isolated sudden onset anosmia in COVID-19 infection. A novel syndrome? Rhinology. 2020. doi: 10.4193/Rhin20.114. [Epub ahead of print].

10. Hopkins C, Surda P, Kumar N. Presentation of new onset anosmia during the COVID-10 pandemic. Rhinology. 2020. doi: 10.4193/ Rhin20.116. [Epub ahead of print].

11. Zou L, Ruan F, Huang M, Liang L, Huang $H$, Hong $Z$, et al. SARS-CoV-2 Viral Load in Upper Respiratory Specimens of Infected Patients. New Eng J Med 2020; 382: 1177 1179.

12. Moran DT, Jafek BW, Eller PM, Rowley III JC. Ultrastructural histopathology of human olfactory dysfunction. Microsc Res Tech. 1992 Oct 15;23(2):103-10

13. O'Donovan J, Tanveer S, Jones, N, Hopkins C, Senior BA, Wise SK, et al. What is the evidence for anosmia as a clinical feature of COVID-19? Centre for Evidence-Based Medicine 2020.

14. Lovato A and de Filippis C. Clinical Presentation of COVID-19: A Systematic Review Focusing on Upper Airway
Symptoms. Ear Nose Throat J. 2020. doi: 10.1177/0145561320920762. [Epub ahead of print].

15. Lechien J, Cabaraux P, Chiesa-Estomba C, Khalife M, Plzak J, Hans S, et al. Objective olfactory testing in patients presenting with sudden onset olfactory dysfunction as the first manifestation of confirmed COVID-19 infection. medRxiv 2020. doi: https://doi.org /10.1101/2020.04.15.20066472.

16. 16. Kaye R CC, Kazahaya K, Brereton J, Denneny III JC. COVID-19 anosmia reporting tool: initial findings. Otolaryngol Head Neck Surg. 2020. doi: 10.1177/0194599820922992. [Epub ahead of print].

17. Menni C, Valdes A, Freydin MB, Ganesh S, El-Sayed Moustafa, J, Visconti A, et al. Loss of smell and taste in combination with other symptoms is a strong predictor of COVID-19 infection. medRxiv 2020. doi: https://doi.org /10.1101/2020.04.05.20048421.

18. Wee LE, Chan YFZ, Teo NWY, Cherng BPZ, Thien SY, Wong HM, et al. The role of selfreported olfactory and gustatory dysfunction as a screening criterion for suspected COVID-19. Eur Arch Otorhinolaryngol. 2020. doi: 10.1007/s00405-020-05999-5. [Epub ahead of print].

19. Beltran-Corbellini A, Chico-Garcia JL, Martinez-Poles J, Rodriguez-Jorge F, Natera- 
Villalba E, Gomez-Corral, et al. Acute-onset smell and taste disorders in the context of Covid-19: a pilot multicenter PCR-based case-control study. Eur J Neurol. 2020. doi: 10.1111/ene.14273. [Epub ahead of print].

20. Levinson R, Elbaz M, Ben-Ami R, Shasha D, Levinson T, Choshen G, et al. Anosmia and dysgeusia in patients with mild SARS-CoV-2 infection. medRxiv 2020. doi: https://doi.org 110.1101/2020.04.11.20055483.

21. Spinato G, Fabbris C, Polesel J, Cazador D, Borsetto D, Hopkins C, et al. Alterations in Smell or Taste in Mildly Symptomatic Outpatients With SARS-CoV-2 Infection. JAMA 2020 2020/04/23.

22. Yan CH, Faraji F, Prajapati DP, Ostrander BT, DeConde AS. Self-reported olfactory loss associates with outpatient clinical course in Covid-19. Int Forum Allergy Rhinol. 2020 doi: 10.1002/alr.22592. [Epub ahead of print]..

23. Lechien JR, Chiesa-Estomba CM, De Siati DR, Horoi M, Le Bon SD, Rodriguez A, et al. Olfactory and gustatory dysfunctions as a clinical presentation of mild-to-moderate forms of the coronavirus disease (COVID19): a multicenter European study. Eur Arch Otorhinolaryngol. 2020. doi: 10.1007/ s00405-020-05965-1. [Epub ahead of print]..

24. Galougahi MK, Ghorbani J, Bakhshayeshkaram M, Naeini AS, Haseli S. Olfactory bulb magnetic resonance imaging in SARS-COV-2-induced anosmia: The first report. Acad Radiol. 2020. doi: 10.1016/j.acra.2020.04.002. [Epub ahead of print].

25. Eliezer M, Hautefort C, Hamel AL, Verillaud B, Herman P, Houdart E, et al. Sudden and complete olfactory loss function as a possible symptom of COVID-19. JAMA Otolaryngol Head Neck Surg. 2020 doi: 10.1001/jamaoto.2020.0832. [Epub ahead of print].
26. Muus C, Luecken MD, Eraslan G, Waghray A, Heimberg G, Sikkema L, et al. Integrated analyses of single-cell atlases reveal age gender, and smoking status associations with cell type-specific expression of mediators of SARS-CoV-2 viral entry and highlights inflammatory programs in putative target cells. bioRxiv 2020. doi: https://doi. org/10.1101/2020.04.19.049254.

27. Butowt R, Bilinska K. SARS-CoV-2: Olfaction, brain infection, and the urgent need for clinical samples allowing earlier virus detection. ACS Chem Neurosci. 2020. doi 10.1021/acschemneuro.0c00172. [Epub ahead of print].

28. Brann DH, Tsukahara T, Weinreb C, Lipovsek M, Van den Berge K, Gong B, et al. Nonneuronal expression of SARS-CoV-2 entry genes in the olfactory system suggests mechanisms underlying COVID-19associated anosmia. bioRxiv 2020 doi https://doi.org/10.1101/2020.03.25.009084.

29. Fodoulian L, Tuberosa J, Rossier D, Landis BN, Carleton A, Rodriguez I. SARS-CoV-2 receptor and entry genes are expressed by sustenacular cells in the human olfactory neuroepithelium. bioRxiv 2020. doi: https:// doi.org/10.1101/2020.03.31.013268.

30. Baig AM, Khaleeg A, Ali U, Syeda, $H$. Evidence of the COVID-19 Virus Targeting the CNS: Tissue Distribution, Host-Virus Interaction, and Proposed Neurotropic Mechanisms. ACS Chemical Neuroscience 2020; 11: 995-998.

31. Paniz-Mondolfi A, Bryce C, Grimes Z, Gordon RE, Reidy J, Lednicky J, et al. Central Nervous System Involvement by Severe Acute Respiratory Syndrome Coronavirus -2 (SARS-CoV-2). J Med Virol 2020. https://doi. org/10.1002/jmv.25915

32. Hummel $T$, Whitcroft $K L$, Andrews $P$, Altundag A, Cinghi C, Costanzo RM, et al. Position paper on olfactory dysfunction.
Rhinology 2016; 56: 1-30.

33. Yao H, Lu X, Chen Q, Xu K, Chen Y, Cheng $L$, et al. Patient-derived mutations impact pathogenicity of SARS-CoV-2. medRxiv 2020. doi: https://doi.org/10.1101/2020.04. 14.20060160.

34. Green K, Allen JA, Suklan J, Beyer FR, Price DA, Graziadio S. What is the role of imaging and biomarkers in the testing strategy for COVID-19? Centre for Evidence-Based Medicine 2020

35. Hunter E, Price, DA, Murphy E, van der Loeff IS, Baker KF, Lendrem D, et al. First experience of COVID-19 screening of health-care workers in England. Lancet 2020. Lancet. 2020;395(10234):e77-e78. doi: 10.1016/ S0140-6736(20)30970-3. Epub 2020 Apr 22.

36. Doty RL, Shaman P, Kimmelman CP, Dann MS. University of Pennsylvania Smell Identification Test: a rapid quantitative olfactory function test for the clinic. Laryngoscope 1984; 94: 176-178.

37. Lee N, Allen Chan KC, Hui DS, Ng EK, Wu A, Chiu RW, et al. Effects of early corticosteroid treatment on plasma SARS-associated Coronavirus RNA concentrations in adult patients. J Clin Virol 2004; 31: 304-309.

\author{
Mr. Matt Lechner \\ Whipps Cross University Hospital \\ Barts Health NHS Trust, \\ London \\ UK
}

E-mail: matt.lechner@nhs.net 


\section{SUPPLEMENTARY INFORMATION}

Supplemental Table 1 Summary of findings from systematic literature review

\begin{tabular}{|c|c|c|c|c|c|}
\hline Reference & Location & Method & Cohort & Summary of Findings & $\begin{array}{l}\text { Further Details of Olfactory } \\
\text { Dysfunction }\end{array}$ \\
\hline $\begin{array}{l}\text { Bagheri et al, } \\
2020\end{array}$ & Iran & $\begin{array}{l}\text { Cross-sectional } \\
\text { survey }\end{array}$ & $\begin{array}{l}\mathrm{n}=10069 ; \text { mean age } \\
32.5,71 \% \text { female; with } \\
\text { new onset anosmia or } \\
\text { hyposmia }\end{array}$ & $\begin{array}{l}\text { Significant correlation } \\
\text { between anosmia and CO- } \\
\text { VID-19 positivity; sudden } \\
\text { symptom onset in } 76.2 \%\end{array}$ & $\begin{array}{l}\text { Nasal stiffness in } 43.7 \% \text {, rhinorrhea } \\
\text { in } 15.63 \%\end{array}$ \\
\hline $\begin{array}{l}\text { Beltran-Corbel- } \\
\text { lini et al., } 2020\end{array}$ & Spain & $\begin{array}{l}\text { Case control } \\
\text { study }\end{array}$ & $\begin{array}{l}n=79 \text { COVID }+, \text { mean } \\
\text { age } 61.6,59.2 \% \text { fema- } \\
\text { les; } n=40 \text { influenza+, } \\
\text { mean age } 61.1,52.5 \% \\
\text { female }\end{array}$ & $\begin{array}{l}\text { New onset olfactory/taste } \\
\text { disturbances more frequent } \\
\text { among COVID+ (39.2\%) than } \\
\text { influenza+ }(12.5 \%)\end{array}$ & $\begin{array}{l}\text { acute onset olfactory/taste disor- } \\
\text { der in } 27 \% \text {, as initial symptom in } \\
35.5 \% ; 80.6 \% \text { with smell disorders; } \\
45.2 \% \text { anosmia, } 29.0 \% \text { hyposmia, } \\
6.5 \% \text { dysosmia; complete recovery } \\
(40 \%) \text { after mean } 7.4 \text { days; partial } \\
\text { recovery ( } 16.7 \% \text { ) after mean } 9.1 \\
\text { days; } 12.9 \% \text { reported concomitant } \\
\text { nasal obstruction }\end{array}$ \\
\hline $\begin{array}{l}\text { Benezit et al, } \\
2020\end{array}$ & France & $\begin{array}{l}\text { Cross-sectional } \\
\text { survey }\end{array}$ & $\begin{array}{l}n=259,68 \text { COVID }+ \text { by } \\
\text { RT-PCR }\end{array}$ & $\begin{array}{l}45 \% \text { hyposmic; strongest asso- } \\
\text { ciation seen with hypogeusia } \\
\text { and hyposmia in patients wit- } \\
\text { hout history of ENT disorders }\end{array}$ & \\
\hline $\begin{array}{l}\text { Drew et al, } \\
2020\end{array}$ & UK & $\begin{array}{l}\text { Cross-sectional } \\
\text { survey }\end{array}$ & $\begin{array}{l}\mathrm{n}=265,851 \text { reporting } \\
\text { COVID+ symptoms, } \\
\text { RT-PCR in } 0.2 \% \text {; mean } \\
\text { age } 41,75 \% \text { female }\end{array}$ & $\begin{array}{l}\text { Anosmia fifth most common } \\
\text { symptom reported, more com- } \\
\text { mon than fever }\end{array}$ & \\
\hline $\begin{array}{l}\text { Eliezer et al, } \\
2020\end{array}$ & France & Case Report & $\mathrm{n}=1$, female in 40 's & $\begin{array}{l}\text { COVID+ by RT-PCR with dry } \\
\text { cough, cephalgia, myalgia } \\
\text { prior to anosmia }\end{array}$ & $\begin{array}{l}\text { CT/MRI showed olfactory cleft } \\
\text { obstructive inflammation, no } \\
\text { changes to olfactory bulb, no nasal } \\
\text { obstruction symptoms }\end{array}$ \\
\hline $\begin{array}{l}\text { Galougahi et } \\
\text { al, } 2020\end{array}$ & Iran & $\begin{array}{l}\text { Olfactory } \\
\text { bulb scanning } \\
\text { in COVID+ } \\
\text { patient with } \\
\text { anosmia }\end{array}$ & $\begin{array}{l}\mathrm{n}=1,27 \text {-year-old } \\
\text { male }\end{array}$ & $\begin{array}{l}\text { MRI showed normal olfactory } \\
\text { bulb volume, normal signal } \\
\text { intensity }\end{array}$ & No sign of nasal congestion \\
\hline $\begin{array}{l}\text { Gane et al, } \\
2020\end{array}$ & UK & Case series & $\begin{array}{l}\mathrm{n}=11, \text { mean age } \\
37.6,27 \% \text { female, all } \\
\text { with anosmia and } \\
\text { symptoms of COVID }\end{array}$ & $\begin{array}{l}\text { One } 48 \text {-year-old male neuro- } \\
\text { surgeon with anosmia tested } \\
\text { COVID+ by RT-PCR, anosmia } \\
\text { as isolated symptom in } n= \\
5, \text { part of other possible CO- } \\
\text { VID-19 symptoms in } n=6\end{array}$ & \\
\hline $\begin{array}{l}\text { Giacomelli et } \\
\text { al, } 2020\end{array}$ & Italy & $\begin{array}{l}\text { Cross-sectional } \\
\text { survey }\end{array}$ & $\begin{array}{l}\mathrm{n}=59 ; \text { median age } \\
60,32 \% \text { female; } \\
\text { COVID+ hospitalised } \\
\text { patients }\end{array}$ & $\begin{array}{l}11.9 \% \text { hyposmic, } 11.9 \% \\
\text { anosmic }\end{array}$ & $\begin{array}{l}20.3 \% \text { reported taste/smell distur- } \\
\text { bance prior to hospital admission, } \\
13.5 \% \text { experienced symptoms } \\
\text { during hospital stay }\end{array}$ \\
\hline $\begin{array}{l}\text { Gudbjartsson } \\
\text { et al, } 2020\end{array}$ & Iceland & $\begin{array}{l}\text { Targeted } \\
\text { testing of high- } \\
\text { risk individuals } \\
\text { and popula- } \\
\text { tion screening }\end{array}$ & $\begin{array}{l}n=4551 \text { (tested by } \\
R T-P C R) ; \text { mean age } \\
44.4 \text { in first round } \\
\text { screening, } 42.0 \text { in se- } \\
\text { cond round screening; } \\
47.7 \% \text { female }\end{array}$ & $\begin{array}{l}\mathrm{n}=528 \text { were COVID }+, 4.4 \% \\
\text { experienced loss of smell; } \\
\text { none in population screening } \\
\text { repoted loss of smell }\end{array}$ & \\
\hline $\begin{array}{l}\text { Gutierrez-Ortiz } \\
\text { et al, } 2020\end{array}$ & Spain & Case Report & $\begin{array}{l}\mathrm{n}=2,50 \text { year-old- } \\
\text { male and } 39 \text {-year-old } \\
\text { male }\end{array}$ & $\begin{array}{l}\text { Patient 1: 2-day history of } \\
\text { vertical diplopia, perioral pa- } \\
\text { raesthesias and gait instability, } \\
\text { diagnosed with Miller-Fisher } \\
\text { Syndrome; reported anos- } \\
\text { mia with other COVID-19 } \\
\text { symptoms; Patient } 2 \text { reported } \\
\text { dysgeusia and had polyneuri- } \\
\text { tis cranialis }\end{array}$ & $\begin{array}{l}\text { Residual anosmia persisted despite } \\
\text { treatment of MF Syndrome }\end{array}$ \\
\hline
\end{tabular}




\begin{tabular}{|c|c|c|c|c|}
\hline Reference & Location & Method & Cohort & Summary of Findings \\
\hline $\begin{array}{l}\text { Heidari et al, } \\
2020\end{array}$ & Iran & Case series & $\begin{array}{l}\mathrm{n}=23, \text { COVID+ with } \\
\text { anosmia, mean age } \\
37.4,65 \% \text { female }\end{array}$ & $\begin{array}{l}83 \% \text { reported anosmia as first } \\
\text { symptom; low grade fever } \\
\text { in } 3 \text { cases, mild myalgia and } \\
\text { fatigue in } 4 \text { cases }\end{array}$ \\
\hline $\begin{array}{l}\text { Hopkins et al, } \\
2020\end{array}$ & UK & $\begin{array}{l}\text { Cross-sectional } \\
\text { survey }\end{array}$ & $\begin{array}{l}n=2428 ; \text { median age } \\
30-39,73 \% \text { female }\end{array}$ & $\begin{array}{l}74 \% \text { of those tested for CO- } \\
\text { VID-19 were positive }(59 / 80) \text {; } \\
13 \% \text { reported anosmia prior } \\
\text { to disease onset, } 38.4 \% \text { at } \\
\text { same time, } 48.6 \% \text { after other } \\
\text { symptoms }\end{array}$ \\
\hline $\begin{array}{l}\text { Jang et al, } \\
2020\end{array}$ & South Korea & Case report & $\begin{array}{l}n=1,42 \text {-year-old } \\
\text { male }\end{array}$ & $\begin{array}{l}\text { anosmia at presentation, only } \\
\text { sign in a contact of a COVID+ } \\
\text { patient; onset } 2 \text { days after } \\
\text { quarantine }\end{array}$ \\
\hline $\begin{array}{l}\text { Kaye et al, } \\
2020\end{array}$ & $\begin{array}{l}\text { International } \\
\text { (USA, Mexico, } \\
\text { Italy, UK and } \\
\text { others) }\end{array}$ & $\begin{array}{l}\text { Cross-sectional } \\
\text { survey }\end{array}$ & $\begin{array}{l}n=237, \text { mean age } \\
39.6,54 \% \text { female }\end{array}$ & $\begin{array}{l}\text { Over } 33 \% \text { reported cases } \\
\text { were from healthcare workers, } \\
\text { anosmia noted in } 73 \% \text { prior to } \\
\text { COVID-19 diagnosis }\end{array}$ \\
\hline $\begin{array}{l}\text { Klopfenstein et } \\
\text { al, } 2020\end{array}$ & France & $\begin{array}{l}\text { Retrospective } \\
\text { series }\end{array}$ & $\begin{array}{l}n=114 \text { COVID+, } n \\
=54 \text { with anosmia; } \\
\text { mean age } 47,67 \% \\
\text { female }\end{array}$ & $\begin{array}{l}47 \% \text { confirmed COVID-19 } \\
\text { reported anosmia }\end{array}$ \\
\hline
\end{tabular}

Further Details of Olfactory Dysfunction Anosmia as only symptom in 16
cases, persisted for a few days Anosmia as only symptom in 16
cases, persisted for a few days

isolatedsymptomipersisted longer

isolated symptom; persisted longer than 2 weeks; no rhinorrhea or nasal obstruction

Anosmia was isolated initial symptom in $26.6 \%$, complete resolution in $13 \%$, partial resolution in $14 \%$, mean time to improvement 7.2 days, nasal congestion prior to anosmia in $25 \%$, rhinorrhea prior to anosmia in $18 \%$

Anosmia never the first or second symptom; third presenting symptom in $38 \%$; developed 4.4 days after infection onset; mean duration was 8.9 days, duration $\geq$ 7 days in $55 \%$, $\geq 14$ days in 20\%; one patient had anosmia persisting beyond 28 days; rhinorrhea in $57 \%$, nasal obstruction in 30\%

$\begin{array}{llll}\text { Lechien et al, Europe } & \text { Cross-sectional } & n=417, \text { COVID+, } & 85.6 \% \text { reported olfactory dys- } \\ 2020 & \text { survey } & \text { mean age 36.9,63\% } & \text { function, 79.6\% were anosmia, } \\ & & \text { female } & 20.4 \% \text { hyposmic }\end{array}$

\begin{tabular}{|c|c|c|c|}
\hline $\begin{array}{l}\text { Lechien et al, } \\
2020 \mathrm{~b}\end{array}$ & Belgium & $\begin{array}{l}\text { Cross-sectional } \\
\text { study }\end{array}$ & $\begin{array}{l}\mathrm{n}=78, \text { mean age } 40.6 \\
59 \% \text { female }\end{array}$ \\
\hline
\end{tabular}

$62 \%$ anosmia $\bigotimes 12$ days with 87.5\% COVID-19 positive; 38\% $>12$ days with $23 \%$ COVID-19 positive

Olfactory dysfunction prior to onset of general/ENT symptoms in $11.8 \%$, after in $65.4 \%$, same time in $22.8 \%$; dysfunction persisted after resolution of other symptoms in $63 \%, \mathrm{n}=76$ did not experience nasal obstruction or rhinorrhea

$52 \%$ anosmic, $24 \%$ hyposmic, $24 \%$ normosmic; of patients with anosmia, $79.1 \%$ reported nasal obstruction symptoms, $64.6 \%$ reported rhinorrhea, $75 \%$ reported postnasal drip

\begin{tabular}{|c|c|c|c|c|}
\hline $\begin{array}{l}\text { Levinson et al, } \\
2020\end{array}$ & Israel & $\begin{array}{l}\text { Cross-sectional } \\
\text { survey }\end{array}$ & $\begin{array}{l}\mathrm{n}=42, \text { COVID + hospi- } \\
\text { talised inpatients with } \\
\text { mild disease; median } \\
\text { age } 34,45 \% \text { female }\end{array}$ & $\begin{array}{l}\text { Anosmia reported in } 35.7 \% \text { of } \\
\text { patients; } n=14 \text { reported both } \\
\text { anosmia and dysgeusia, } n=1 \\
\text { reported only anosmia }\end{array}$ \\
\hline $\begin{array}{l}\text { Lorenzo-Vilal- } \\
\text { ba et al, } 2020\end{array}$ & France/Spain & Case reports & $\begin{array}{l}\mathrm{n}=2,85 \text {-year-old } \\
\text { male and } 80 \text {-year-old } \\
\text { female }\end{array}$ & $\begin{array}{l}\text { Anosmia presented early in } \\
\text { disease; one patient died of } \\
\text { ARDS after } 5 \text { days }\end{array}$ \\
\hline Mao et al, 2020 & China & $\begin{array}{l}\text { Retrospective } \\
\text { observational } \\
\text { case series }\end{array}$ & $\begin{array}{l}\mathrm{n}=214, \text { COVID }+ \\
\text { mean age } 52.7,59.3 \% \\
\text { female }\end{array}$ & $\begin{array}{l}\text { Smell impairment in } 5.1 \% \text {, } \\
3 / 88 \text { in severe patients, } 8 / 126 \\
\text { in non-severe patients }\end{array}$ \\
\hline $\begin{array}{l}\text { Marchese- } \\
\text { Ragona et al, } \\
2020\end{array}$ & Italy & Case series & $\begin{array}{l}\mathrm{n}=6 \text {; patients presen- } \\
\text { ting with hyposmia as } \\
\text { main/only symptom; } \\
\text { mean age } 32.3,67 \% \\
\text { female }\end{array}$ & \\
\hline
\end{tabular}

Anosmia and dysgeusia started median 3.3 days post disease onset; $73.3 \%$ with anosmia reported recovery, median 7.1 days for dysgeusia, 7.6 days for anosmia

85-year-old male experienced sudden onset of anosmia and fatigue prior to admission, died on day 6 after presentation; 80-year-old female had a 5-day history of taste loss prior to smelling problems and fatigue

Onset 1 day prior to admission in severe patients, 2 days prior to admission in non-severe patients

1 patient had fever after smell dysfunction, 2 patients reported myalgia one day prior to onset of hyposmia and mild dry cough after hyposmia 


\begin{tabular}{|c|c|c|c|c|c|}
\hline Reference & Location & Method & Cohort & Summary of Findings & $\begin{array}{l}\text { Further Details of Olfactory } \\
\text { Dysfunction }\end{array}$ \\
\hline $\begin{array}{l}\text { Menni et al, } \\
2020\end{array}$ & UK & $\begin{array}{l}\text { Cross-sectional } \\
\text { survey }\end{array}$ & $\begin{array}{l}n=579, \text { COVID }+ \\
\text { mean age } 40.79,69 \% \\
\text { female; } n=1123 \text { con- } \\
\text { trols, mean age } 41.22, \\
74 \% \text { female }\end{array}$ & $\begin{array}{l}\text { Loss of smell and taste in } \\
59.4 \% \text { COVID+, } 18.97 \% \text { CO- } \\
\text { VID-; positive predictive value } \\
=61.7 \%\end{array}$ & \\
\hline $\begin{array}{l}\text { Moein et al, } \\
2020\end{array}$ & Iran & $\begin{array}{l}\text { Cross-sectional } \\
\text { study }\end{array}$ & $\begin{array}{l}n=120 \text { hospitalised } \\
\text { patients; mean age } \\
46.6,33 \% \text { for COVID+; } \\
\text { mean age } 46.6,33 \% \\
\text { female for controls }\end{array}$ & $\begin{array}{l}\text { 35\% of COVID+ reported taste/ } \\
\text { smell complaint, } 98.3 \% \text { had ol- } \\
\text { factory dysfunction by UPSIT; } \\
\text { no controls reported smell/ } \\
\text { taste problems, } 18 \% \text { had mild } \\
\text { microsmia by UPSIT; mean } \\
\text { UPSIT for COVID+ was } 20.98 \text {, } \\
34.10 \text { for controls }\end{array}$ & \\
\hline $\begin{array}{l}\text { Ollarves-Carre- } \\
\text { ro et al, } 2020\end{array}$ & Spain & Case report & $\begin{array}{l}n=1,40 \text {-year-old } \\
\text { female }\end{array}$ & $\begin{array}{l}\text { Anosmia presented } 2 \text { days } \\
\text { after myalgia, headache, chills, } \\
\text { abdominal pain and diarrhea; } \\
\text { at same time as cough }\end{array}$ & $\begin{array}{l}\text { Gradually improved and resolved } \\
\text { after } 14 \text { days }\end{array}$ \\
\hline $\begin{array}{l}\text { Paoli et al, } \\
2020\end{array}$ & Italy & Case Report & $\begin{array}{l}\mathrm{n}=1,31 \text {-year-old } \\
\text { male }\end{array}$ & $\begin{array}{l}\text { Anosmia after onset of other } \\
\text { typical symptoms }\end{array}$ & \\
\hline $\begin{array}{l}\text { Spinato et al, } \\
2020\end{array}$ & Italy & $\begin{array}{l}\text { Cross-sectional } \\
\text { survey }\end{array}$ & $\begin{array}{l}\mathrm{n}=202 \text { COVID+ } \\
\text { patients; median age } \\
56,52.0 \% \text { female }\end{array}$ & $\begin{array}{l}\text { Change to smell or taste repor- } \\
\text { ted by } 64.4 \%\end{array}$ & $\begin{array}{l}\text { Occurred before other symptoms } \\
(11.9 \% \text {, at the same time }(22.8 \%) \\
\text { or after other symptoms }(26.7 \%) \text {; } \\
34.6 \% \text { with smell dysfunction also } \\
\text { reported blocked nose }\end{array}$ \\
\hline $\begin{array}{l}\text { van Damme et } \\
\text { al, } 2020\end{array}$ & Belgium & Case report & $\begin{array}{l}n=1,39 \text {-year-old } \\
\text { female }\end{array}$ & $\begin{array}{l}\text { Report of a nurse with onset of } \\
\text { rash followed by pyrexia and } \\
\text { headache, subsequently deve- } \\
\text { loped anosmia and dysgeusia }\end{array}$ & $\begin{array}{l}\text { Anosmia onset } 1 \text { week after other } \\
\text { symptoms, recovered after } 1 \text { week; } \\
\text { also reported rhinorrhea }\end{array}$ \\
\hline Wee et al, 2020 & Singapore & $\begin{array}{l}\text { Prospective } \\
\text { study }\end{array}$ & $\begin{array}{l}\mathrm{n}=870 \text { suspected } \\
\text { COVID patients }\end{array}$ & $\begin{array}{l}17.9 \% \text { of suspected patients } \\
\text { tested positive; } 22.7 \% \text { of these } \\
\text { had olfactory/taste disturban- } \\
\text { ce; high specific of olfactory } \\
\text { dysfunction as screening crite- } \\
\text { rion for COVID-19 }(98.7 \%) \text { but } \\
\text { lower sensitivity }(22.7 \%)\end{array}$ & $\begin{array}{l}3 / 35 \text { presented with isolated } \\
\text { anosmia; rhinorrhea in } 28.5 \% \text {; } \\
\text { COVID+ patients had higher odds } \\
\text { of olfactory/taste disturbance com- } \\
\text { pared to those positive for other } \\
\text { respiratory viruses }(\mathrm{OR}=10.14, \mathrm{p} \\
<0.001 \text { ) }\end{array}$ \\
\hline $\begin{array}{l}\text { Xydakis et al, } \\
2020\end{array}$ & Unavailable & Letter & $\mathrm{n}=1$ & $\begin{array}{l}\text { COVID+ with anosmia and } \\
\text { dysgeusia }\end{array}$ & $\begin{array}{l}\text { Traditional nasal manifestations as } \\
\text { seen with other upper-respiratory } \\
\text { infections typically absent with } \\
\text { COVID+, often no significant nasal } \\
\text { congestion or rhinorrhea }\end{array}$ \\
\hline Yan et al, 2020 & USA & $\begin{array}{l}\text { Cross-sectional } \\
\text { survey }\end{array}$ & $\begin{array}{l}n=59, \text { COVID }+, 49 \% \\
\text { female; } n=203 \text { CO- } \\
\text { VID- } 65 \% \text { female }\end{array}$ & $\begin{array}{l}\text { Olfactory dysfunction in } 68 \% \\
\text { of COVID+, } 16 \% \text { of COVID- }\end{array}$ & $\begin{array}{l}22 \% \text { reported anosmia at initial } \\
\text { presentation of disease, } 74 \% \text { had } \\
\text { return of function ( } 18 \%<1 \text { week, } \\
37.5 \% \text { by } 1-2 \text { weeks, } 18 \% \text { by } 2-4 \\
\text { weeks); nasal obstruction in } 47.5 \% \\
\text { of COVID+, } 44.8 \% \text { COVID-; rhinor- } \\
\text { rhea reported in } 30.5 \% \text { of COVID+, } \\
40.9 \% \text { of COVID- }\end{array}$ \\
\hline $\begin{array}{l}\text { Yan et al, } \\
2020 b\end{array}$ & USA & $\begin{array}{l}\text { Retrospective } \\
\text { review }\end{array}$ & $\begin{array}{l}n=128 \text { COVID+ } \\
\text { patients, median age } \\
53.5,65 \% \text { female for } \\
\text { admitted patients, } \\
49 \% \text { for outpatients }\end{array}$ & $\begin{array}{l}\text { Anosmia strongly and inde- } \\
\text { pendently associated with pa- } \\
\text { tients remaining in outpatient } \\
\text { care; } 10 \text {-fold less chance to be } \\
\text { admitted than normosmia }\end{array}$ & $\begin{array}{l}\text { Rhinorrhoea in } 1 \text { admitted patient, } \\
15.7 \% \text { of outpatients; nasal } \\
\text { obstruction in } 15.4 \% \text { admitted } \\
\text { patients and } 30.4 \% \text { of outpatients }\end{array}$ \\
\hline
\end{tabular}

